DOI : 10.31357/fhssphd.2012.00703

\title{
A Critical Analysis of Residential Locations in the City of Colombo
}

\author{
By
}

Ranthilaka Gedara Ariyawansa

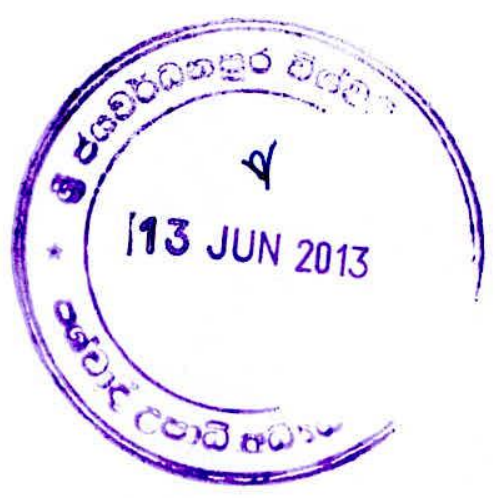

Ph.D. 


\title{
A Critical Analysis of Residential Locations in the City
}

\author{
of Colombo
}

By

Ranthilaka Gedara Ariyawansa

Thesis Submitted to the University of Sri Jayewardenepura for the award of the Degree of Doctor of Philosophy in Geography

$$
\text { on } 16^{\text {th }} \text { July } 2012
$$




\section{DECLARATION OF THE CANDIDATE}

This research study for the $\mathrm{PhD}$ thesis was conducted by me under the supervision of $\mathrm{Dr}$. N L A Karunaratne, Vice Chancellor of the University of Sri Jayewardenepura and Senior Lecturer of the Department of Geography of the University of Sri Jayewardenepura. I certify that this thesis has not been submitted in whole or in part to any university or any other institution or any other degree or diploma. Also, I declare that all the corrections, amendments, and additions recommended by the examiners have been incorporated.
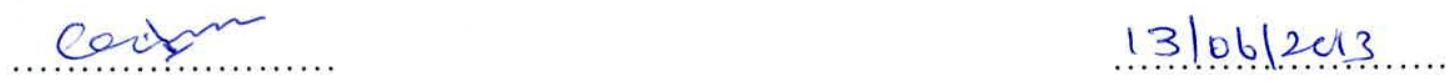

R G Ariyawansa

Date

PhD Candidate

\section{DELARATION OF THE SUPERVISOR}

I certify that the candidate has incorporated all corrections, amendments, and additions recommended by the examiners.
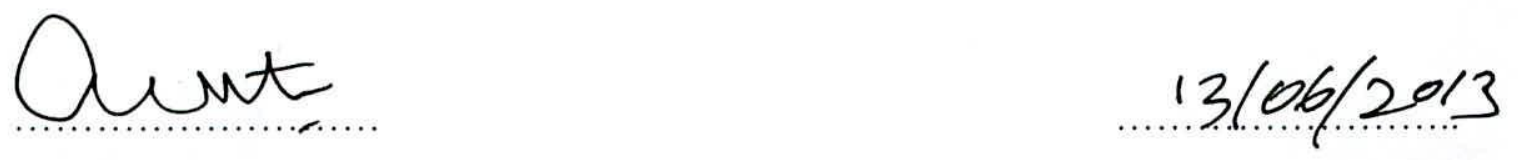

Dr. N L A Karunaratne

Date

Vice Chancellor

University of Sri Jayewardenepura

Senior Lecturer

Department of Geography

University of Sri Jayewardenepura 


\section{ACKNOWLEDGEMENTS}

It is a great pleasure to me to have the feeling of completion of this doctoral thesis after engaged in a series of heavy work during the last few years. For this remarkable achievement, my personal potentials were able to make use of only as a result of invaluable assistance rendered by many superior and resourceful personals. Hence, I would like to remind the names of those who were behind this successful endeavor.

First of all, I am pleased to offer my sincere gratitude to my supervisor Dr. N L A Karunaratne, Vice Chancellor of the University of Sri Jayewardenepura, and Senior Lecturer of the Department of Geography, Faculty of Humanities and Social Sciences of the University of Sri Jayewardenepura for his continuous instructions, encouragements specially through maintaining humanitarian relationship with me, which, as I firmly believe, is a fundamental requirement for this type of comprehensive work. Unless otherwise, his understanding, prudent, and democratic as well as humanitarian assistance, it would not be an easy and possible task of completing a $\mathrm{PhD}$ degree. I salute for his complete understanding of and granting me academic freedom, independence learning and orientation of practical research, which are needed for the real world development.

I am grateful for former Heads and present Head of the Department of Geography, University of Sri Jayewardenepura, for granting me a valuable opportunity by accepting my candidature as a doctoral student of the Department and continuous assistance for necessary official procedures enabling me to work at a very democratic and pleasant atmosphere. 
My special thank goes to Professor C K M Deheragoda, former Chairman of the Board of Study of Social Sciences, Faculty of Graduate Studies, University of Sri Jayewardenepura for his valuable assistance to successfully completion of all official procedures in conducting seminars and getting extensions for academic periods etc. For such events, his highly scholastic and constructive advices provided me with correct directions needed at some critical junctions of this painstaking path.

The name of Emeritus Professor (Mrs.) Y A D S Wanasinhe of the Department of Geography, University of Sri Jayewardenepura is presented here with full of gratitude for sharing her wide experience, knowledge and other qualities with me by providing advices, guidelines and necessary materials etc as an external member of the Board of Studies for evaluation of my seminars.

I specially remind the name of Senior Professor Swarna Piyasiri, Dean of the Faculty of Graduate Studies, University of Sri Jayewardenepura, for her invaluable advices, encouragement and other official assistance.

Also my special thank should go to Professor Tennison Perera, Department of Sociology and Anthropology, for his invaluable assistance rendered to me from the beginning up to the end of my research.

Provision of official facilities and continuous encouragement for obtaining doctoral qualification as an academician, my special thanks should go to professor S P P Amaratunge, Dean of the Faculty of Management Studies and Commerce, University of Sri Jayewardenepura. I also remind the name with appreciation of former Dean of the 
Faculty of Management Studies and Commerce, Mr. Hilary Elmo Silva for his kind help during his tenure particularly in forwarding my fund application.

My special word of appreciation goes to Professor Michal Lyons, Director of Doctoral Studies, and the former Dean of the Faculty of Built Environment, University of London Southbank, London, UK, for her founding supervisory assistance for my doctoral studies. Also my sincere thanks should be presented to Professor Ali Grambiyal Parsa, University of London Southbank, London, UK for his supervisory assistance jointly with Professor Michal.

Further, I am thankful to Professor Laksiri Fernando, Professor Dayalal Abesekera, former Directors and Dr. R M Ratnayake, present Director of the National Centre of Advanced Studies (NCAS) for providing training opportunities for research methods and financial assistance, continuous encouragement for the successful completion of this study.

I am very much grateful for all supported officers of National Housing Development Authority, Urban Development Authority, Colombo Municipal Council, all households who provided necessary data and information, and my colleagues who assisted for data collection and analysis.

Former Head and the current Head of the Department of Estate Management and Valuation and all of my colleague staff members are mentioned with appreciation for their supports in numerous ways in completion of this research. 
Last but not least, I am grateful for my affectionate wife Rasanjalee and my beloved son Asinshana for their wönderful assistance by being patient and embracing overwhelming happiness over my success.

R G Ariyawansa

16.07.2012 


\section{ABSTRACT}

\section{A Critical Analysis of Residential Locations in the City of Colombo}

Land and landed property related disciplines, which are concerned with the concept of "location", argue that allocation of land for residential properties should encourage the overall development of cities. This means that residential properties and cities should be mutually benefited ensuring the "rational land use" in cities. Decisions related with residential locations are extremely difficult due to diverse and complex economic and non-economic factors. Therefore, methodical examinations over the suitability of locations are essential in order to reach objective decisions since the implications of such decisions are highly expensive in financially and socially. Since land in Colombo city is highly scarce and expensive resource, economic potentials of land for the city development should be critically analyzed. Hence, this study questions whether the residential property locations are able to fulfil households' aspirations, and how far the households are contributing to make their property locations to be rational land uses integrating with the entire city.

Throughout the study, it was generally aimed to conduct a critical analysis of residential locations in the city of Colombo. It was planned to achieve three specific objectives namely, to analyze the general situation of the residential properties in the city, to evaluate the views of households on residential locations in terms of their satisfaction and to assess their value addition to the lands. 
This research is based on both qualitative and quantitative approaches. Observations, survey, interviews, and discussions with the help of structured questionnaire were used as data collection techniques. A stratified random sample of 200 households from 04 public sector low-income housing schemes in the Colombo city was used to collect primary data. As the primary data, views of households were collected on different housing and household attributes with regard to the rationality and suitability of locations of settlements in terms of households' satisfaction and value addition made to their previous and present lands. This study primarily focused on six major variables such as, 1) physical, 2) functional, 3) economic, 4) behavioural, 5) environmental, and 6) time (durability) aspects of residential locations.

Secondary data was gathered from institutions such as the Urban Development Authority, National Housing Development Authority, Colombo Municipal Council, Central Bank of Sri Lanka, Department of Census and Statistics, Resource Centre of the Department of Estate Management and Valuation, research papers and websites.

Initially a descriptive analysis was done using full counts and percentages as well as some descriptive statistics facilitated by SPSS-16 and MS-Excel 2007. Secondly, it was computed Weighted Averages and developed separate sets of values for the investigated variables to support for comparative analysis between previous and new locations. This was done with the help of "Scatter Diagrams" and "Coefficient of Determination $\left(\mathrm{r}^{2}\right)$ ".

Study recognized that there is a potential market for low-income housing with rental or leasehold ownerships rather than freehold ownerships. Along with the transferring of 
ownership of public houses to households, formal market transactions such as renting and leasing also have been increased. However, maintenance of housing schemes seems to be a growing issue. The study also found that households' income and expenditure have been tremendously increased in their new locations. However, still the rate of investment mode of money allocations among the low-income households is slowly being increased.

It was identified that the availability of employment opportunities around their new locations has not drastically been changed. Accordingly, it is needed to generate formal sector job opportunities rather than informal odd-jobs that help to increase households' satisfaction and value addition to their lands. Also it was noticed that the increasing elderly population has not been specially considered at new locations.

Overall, it was found that there is a positive but weak correlation between "Significant Factors" and "Value Addition" in previous locations. Similarly, there is a positive but weak correlation between "Significant Factors" and "Satisfaction" in previous locations. Thus, as per the households' views, previous locations were comparatively less rational locations for residential properties in the city of Colombo. Regarding the new locations, it was found positive and strong relationship between "Significant Factors" and "Households' Satisfaction" and also it was found a positive and somewhat strong relationship between "Households' Satisfaction" and Value Addition" at new locations. Thus, the study argues that the new locations are more rational and suitable residential locations in the city of Colombo compared to the previous locations. Formal education on investment, money expenditure, entrepreneurial skills etc will help to increase the households' value addition to land in new locations as their satisfaction is very high. 


\section{TABLE OF CONTENTS}

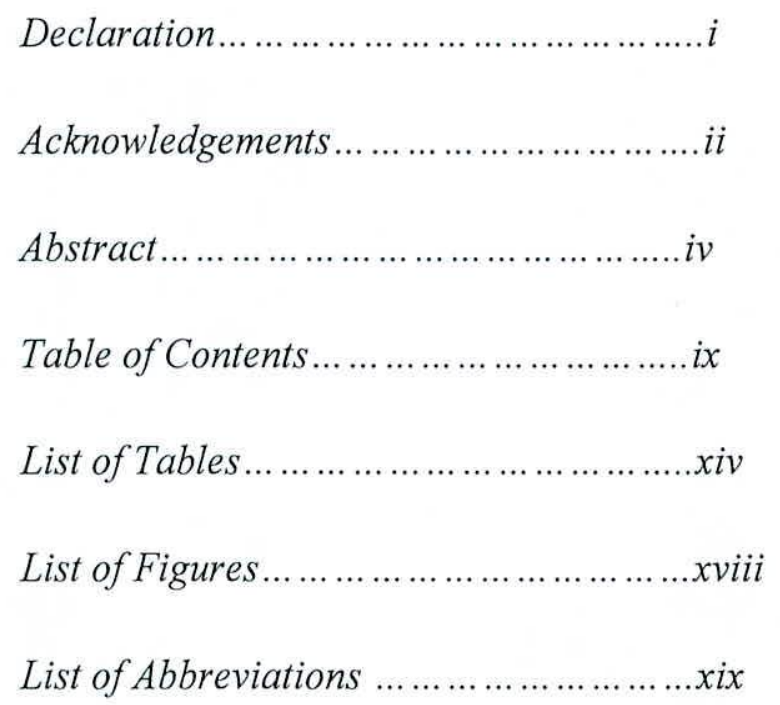

Contents

Page No

CHAPTER ONE

INTRODUCTORY INFORMATION ON STUDY OF

A Critical Analysis of Residential Locations in the City of Colombo

01.01. Background of the Study 1

01.02. Rational Use of Land for Higher Value 4

01.03. Theoretical Epigram on Locations 7

01.04. Significance of the Study 8

01. 04.01. Locations for Urban Residential Properties: A Global Issue 8

01. 04.02. Residential Location Related Issues in Colombo 10

01. 04.03. Policy Implications 13

01.05. Research Problem 16

$\begin{array}{ll}\text { 01.06. Objectives } & 17\end{array}$

01.07. The Way of Achieving the Objectives 19

01.08. Limitations of the Study 19

01.09. Organization of Chapters in the Thesis 19 


\section{CHAPTER TWO}

\section{LITERATURE ANALYSIS}

\section{Critical Analysis on Residential Locations in Different Contexts}

02.01. Introduction 23

02.02. Overview of Residential Locations 25

02.03. Philosophical Perspectives on Location 28

02.04. Urban Economists' Views on Property Locations 29

02.04.01. Forces Driving the New Economic Geography 30

02.05. Business Processing Outsourcing (BPO) over Property Locations and Corporate Real Estate Assets Management (CREAM) 31

02.06. Location Theories and Models 35

02.06.01. Theories of Urban Impact on Residential Location 35

02.06.02. Gentrification Theory $\quad 39$

02.06.03. Travel Cost and Affordability 39

02.07. Industrial Property Location 41

02.07.01. Cost Minimization Approach of Location 41

02.07.02. Market Area Analysis 41

02.08. Other Theories of Urban Spatial Structure 43

02.08.01. Concentric Zone Model 43

02.08.02. Sector Model 44

02.08.03. Multiple Nuclei Model 45

02.08.04. Christaller's Central Place Theory 46

02.09. Macro-Economic Models 47

02.09.01. Economic Base Theory 47

02.09.02. Input-Output Analysis 48

02.09.03. Keynesian Model 49

02.10. Empirical Views on Property Locations 50

02.11. Key Determinants of Residential Location 53

02.12. Suitability of Locations of Residential Properties Vs. Households' Needs 54

02.12.01. Fair and Suitable Housing 58

02.12.02. Key Variables of Suitable Locations for Residential Properties 60

02.13. Suitable Residential Properties in Markets as a Global Issue 71

02.13.01. Non-Residential Property Demand 72 
02.13.02. Public Policy Implications and Real Estate Industry Behavior 74

02.13.03. Market Dynamism 75

02.13.04. Location Issues in Developing Cities 76

02.14. Households' Aspirations from Residential Locations 80

02.14.01. Households' Satisfaction and Households' Value Addition to Land 81

02.15. Summary 82

CHAPTER THREE

DESCRIPTION OF THE STUDY AREA

City of Colombo

03.01. Introduction 84

03.02. Location and the Administrative Structure of the City 84

03.03. Socio-economic Significance of the City 88

03.04. Evolution of the City 90

03.05. Basic Demographic Characteristics of Colombo 91

03.06. Land Use Pattern of the City 94

03.07. Land Tenure Pattern in the City 97

03.08. Infrastructure Services for Land Development and Use 99

03.09. Colombo's 2020 Vision 100

03.10. Housing in the City 103

03.11. Condominium Market in Colombo 107

$\begin{array}{ll}\text { 03.12. SWOT on the City of Colombo } & 108\end{array}$

CHAPTER FOUR

CONCEPTUAL FRAMEWORK AND METHODOLOGY

The Design of the Study on Rational Residential Locations

04.01. Introduction 116

04.02. Working Definitions 117

04.03. Views of Different Philosophers and Experts 120

04.04. Recent Studies on Property Locations 125

04.05. Methodology of the Study 135

$\begin{array}{ll}\text { 04.06. Data Used for the Study } & 137\end{array}$ 
04.07. Sampling Techniques

\section{CHAPTER FIVE}

\section{DATA PRESENTATION AND ANALYSIS}

General Situation of Residential Properties, Households' Satisfaction and Value Addition to Lands

05.01. Introduction

05.02. Residential Properties in Colombo with Special Reference to Public Housing

05.02.02. Demand for Housing in the Country and the Colombo city

05.02.03. Nature of Household Composition

05.02.04. Details of Housing Units

05.02.05. Housing Supply in Colombo

05.03. Issues of Public Housing Schemes

05.04. Households' Views According to the Previous Studies

05.05. Households' Views on Satisfaction and the Value Addition to their Lands

05.05.01. Socio-Economic and Demographic Background of the Sample

05.05.02. Aspects of Properties Belong to Households

05.05.03. Households' Satisfaction over Housing units

05.05.04. Comparison of Satisfaction of Previous and Current Locations

05.05.05. Households' Value Addition to Lands

05.05.06. Significant Factor of a Housing Location

\section{CHAPTER SIX}

\section{CONCLUSIONS OF THE STUDY}

\section{Discussion of Findings and Recommendations for Policy Formation}

06.01. Introduction

06.02. General Situation of the Residential Locations in the City of Colombo 
06.03.01. Demographic Structure of Households

06.03.02. Educational Background of Households

06.03.03. Economic Background of Households

06.03.04. Properties Belong to Households

06.04. Households' Satisfaction 267

06.04.01. Satisfaction for Previous Locations 267

06.04.02. Satisfaction for Preset Housing Locations 268

06.04.03. Average Satisfaction for the New Locations 269

06.04.04. Weighted Average of Satisfaction 270

06.05. Satisfaction of Previous and Current Housing Locations 270

06.06. Households' Value Addition to Lands 271

06.07. Significant Factor of a Housing Location 273

06.08. Comparison of Satisfaction, Value Addition and Significant Factor 273

06.09. Recommendations 274

06.10. Summary 276

List of References $\quad 278$

$\begin{array}{ll}\text { Appendixes } & 301\end{array}$ 